\title{
Defective Production of Interleukin-6 by Monocytes: A Possible Mechanism Underlying Several Host Defense Deficiencies of Neonates ${ }^{1}$
}

\author{
KURT R. SCHIBLER, KENNETH W. LIECHTY, WILLIAM L. WHITE, GERALD ROTHSTEIN, \\ AND ROBERT D. CHRISTENSEN
}

Division of Human Development and Aging and Division of Neonatology, Department of Pediatrics, and the Clinical Research Center, University of Utah School of Medicine and the Salt Lake City Veterans Administration Medical Center, Salt Lake City, Utah 84132

\begin{abstract}
Several deficiencies in antibacterial defense have been described in neonates. Among those best characterized are delayed maturation of $B$ cells into antibody producing cells, deficient $\mathrm{T}$-cell maturation, and delayed cycling of hematopoietic progenitor cells after an infectious challenge. No unifying theory has been forwarded, however, to explain the concomitance of these three developmental deficiencies. IL-6, a cytokine produced primarily by monocytes and macrophages in response to stimulation by $\mathrm{IL}-1$, is involved in the regulation of these three processes. Thus, we postulated that defective production of IL6 could be a mechanism underlying these immune deficiencies of neonates. Indeed, we observed that at peak production, cells of five term neonates produced only one half as much IL-6 (14 $120 \pm 2590 \mathrm{pg}$ IL-6/10 6 monocytes) as those of five adults $(28940 \pm 1680 \mathrm{pg}, p<0.001)$. Peak production was lower still by monocytes of six preterm neonates $(7190 \pm 1400 \mathrm{pg}, p<0.001$ versus term). Production of IL-6 protein was inhibited by actinomycin D and the IL-6 mRNA content of monocytes from neonates, as assessed by competitive polymerase chain reaction, was less than that of adult monocytes. We speculate that defective IL-6 transcription might underlie some of the defects in immune regulation observed in neonates. (Pediatr Res 31: 18-21, 1992)
\end{abstract}

\section{Abbreviations}

PCR, polymerase chain reaction

LPS, lipopolysaccharide

Infectious diseases are among the major causes of morbidity and mortality in neonates (1). Human and animal studies indicate that, compared with adults, neonates have an increased susceptibility to acquiring certain infections (2-4) and when infected have an increased likelihood of developing a severe resultant illness (4-6). This increased susceptibility is particularly marked among neonates delivered prematurely.

The reduced host defense status of neonates appears to be the result of multiple factors, including hyporesponsiveness of $\mathrm{B}$

Received May 10, 1991; accepted August 8, 1991

Correspondence: Robert D. Christensen, M.D., Division of Human Development and Aging, University of Utah, 50 North Medical Drive, Salt Lake City, UT 84132 .

Supported by Grants HL-44951 and RR-00064 from the National Institutes of Health and a merit award from the Veterans Administration.

${ }^{1}$ Presented in part at the 1991 annual meeting of the Society for Pediatric Research, New Orleans, LA. cells, T cells, and granulocytes, and reduced quantities of granulocytes and their progenitors $(7,8)$. Specific defects include delayed maturation of B cells into antibody-producing cells (9_ 12 ), deficient stimulation of $\mathrm{T}$-cell maturation (13-15), and delayed induction of hematopoietic progenitor cell cycling (16). The clinical deficiencies resulting from these immature cellular processes include blunted synthesis of specific $\operatorname{IgG}(12,17,18)$ and delayed up-regulation of neutrophil production $(19,20)$.

Although these developmental deficiencies are well described individually, no unifying theory has been forwarded to explain their concomitance. Indeed, if a common underlying defect were identified, such recognition might form the basis of new strategies for the prevention or treatment of neonatal infections.

Striking similarities are observed between the actions of the cytokine IL- 6 and the host defense deficiencies of neonates listed above. Specifically, IL-6, which is produced primarily by monocytes and macrophages in response to inflammatory mediators such as IL-1 $(21,22)$, induces antigen-specific antibody production by $\mathrm{B}$ cells $(23,24)$, stimulates T-cell growth and differentiation $(25,26)$, and induces hematopoietic progenitor cells from the quiescent state into active cell cycle $(27,28)$. Thus, we postulated that a defective capacity to generate IL-6 might underlie several of the host defense defects observed in neonates. The following experiments were designed to assess the kinetics of IL- 6 production by monocytes obtained from adults and from term and preterm neonates.

\section{MATERIALS AND METHODS}

Subjects. Blood was obtained from five healthy adults by venipuncture and from five term neonates and six preterm neonates (23-34 wk gestation) by needle puncture of an umbilical vessel immediately after delivery. Exclusion criteria for infants included infection, fetal distress, and presence of congenital anomalies. The studies were performed in accordance with protocols approved by the University of Utah Institutional Review Board, and informed consent was obtained from the participants.

Preparation of cells. Blood mononuclear cells were obtained by density centrifugation with Ficoll-Hypaque (sp gr $<1.077$ ). Monocyte-enriched populations were obtained by incubating mononuclear cells with murine antibodies directed against human T lymphocytes (anti-human leu- 1 and anti-human leu-5b; Becton Dickinson, San Jose, CA), B lymphocytes (anti-human leu-12), progenitor cells (anti-human progenitor cell antigen-1), and nucleated red blood cells (anti-glycophorin antibodies kindly supplied by Dr. Richard Langlois, Lawrence Livermore Laboratories, Livermore, CA). The antibody-bound cells were partitioned from the remaining mononuclear cells using magnetic beads coated with goat anti-mouse antibodies (Dynal Inc., Great Neck, NY). The plated cells from adults consisted of $91 \pm 3 \%$ 
monocytes (mean $\pm \mathrm{SD}$ ), and those from term and preterm neonates contained $94 \pm 3 \%$ and $88 \pm 4 \%$ monocytes, respectively, as determined by staining with $\alpha$-naphthyl esterase (Sigma Diagnostics, St. Louis, MO). Cells $\left(0.5 \times 10^{6}\right.$ cells/well $)$ were plated under serum-free conditions using minimal essential medium with alpha modification (Hyclone Laboratories, Logan, UT) plus $1 \%$ nutridoma (Boehringer Mannheim, Indianapolis, IN) and incubated with various concentrations of IL-1- $\alpha$ (R\&D Systems, Minneapolis, $\mathrm{MN} ; 0-20 \mathrm{ng} / \mathrm{mL})$ in $5 \% \mathrm{CO}_{2}$ at $37^{\circ} \mathrm{C}$. In other studies, monocytes were incubated with IL-1 $(10 \mathrm{ng} /$ $\mathrm{mL})$ alone or in combination with actinomycin $\mathrm{D}(1 \mu \mathrm{g} / \mathrm{mL}$ from Sigma Chemical Co., St. Louis, MO). Purified recombinant human IL- $1-\alpha$ had a sp act of $\geq 5 \times 10^{8}$ units/mg and a purity of $\geq 95 \%$ by SDS-PAGE. Endotoxin (LPS) concentrations in the reagents were less than $0.05 \mathrm{ng} / \mathrm{mL}$. Supernatants were assayed for IL-6 using ELISA (R\&D Systems).

$R N A$ isolation. Monocytes $\left(10^{6} / \mathrm{mL}\right)$ were obtained from the blood of five adults and five term neonates. After 4 and $12 \mathrm{~h}$ of incubation with $5 \mathrm{ng} \mathrm{IL}-1 / \mathrm{mL}$, RNA was extracted using a guanidinium thiocyanate extraction buffer, isolated by centrifugation through a cesium chloride gradient, and purified by phenol chloroform extraction (29).

Reverse transcriptase reaction. First strand DNA, required for the subsequent competitive PCR, was prepared from RNA using a modification of the procedure described by Sambrook et al. (29). Briefly, $0.1 \mu \mathrm{g}$ of total cellular RNA was incubated with 200 U of Moloney Murine Leukemia Virus Reverse Transcriptase (Gibco BRL, Gaithersburg, MD) for $1 \mathrm{~h}$ at $37^{\circ} \mathrm{C}$. Reaction components included $50 \mathrm{mM} \mathrm{KCl} ; 10 \mathrm{mM}$ Tris-Cl, $\mathrm{pH} 8.3 ; 1.5$ $\mathrm{mM} \mathrm{MgCl} ; 0.01 \%$ gelatin; $1 \mathrm{mM}$ DTT; 100 pmol of random hexamers (Boehringer Mannheim, Indianapolis, IN); $500 \mu \mathrm{M}$ deoxynucleotide triphosphates (Perkin Elmer Cetus, Norwalk, $\mathrm{CT}$ ), and $40 \mathrm{U}$ of RNAasin placental ribonuclease inhibitor (Promega, Madison, WI) in a final reaction volume of $20 \mu \mathrm{L}$. The reverse transcriptase was heat-inactivated at $95^{\circ} \mathrm{C}$ for $5 \mathrm{~min}$.

Competitive template preparation. A 314-bp fragment of the human IL- 6 gene between positions 1223 and 1536 (Kishimoto $\mathrm{T}$ et al., Genebank Accession Y00081) was amplified, using PCR, from high molecular weight DNA isolated from L-2379 K 1462, a lymphoblastoid cell line. This fragment is in the $5^{\prime}$ coding region of the IL-6 gene and includes the 18 bp in exon 1 , the entire $153 \mathrm{bp}$ of intervening sequence 1 , and the first $142 \mathrm{bp}$ of exon 2. The primer pair used was upstream primer $5^{\prime}$-ATG AAC TCC TTC ACA-3' and downstream primer 5'-CAA TTC GTT CTG AAG AGG-3'. These same primers amplify the $161-$ bp fragment from the reverse transcribed IL- 6 mRNA.

Competitive PCR. The competitive PCR techniques used in this study are modifications of methods previously described (30-32). Briefly, $1 \mathrm{pg}$ of competitive template DNA in $10 \mu \mathrm{L}$ water was added to each $0.65-\mathrm{mL}$ microcentrifuge tube. Samples were overlayed with mineral oil, heat-denatured for $10 \mathrm{~min}$ at $94^{\circ} \mathrm{C}$, and quenched in ice. A master mix was prepared and added on ice such that the final concentration of reagents for each sample was $2.5 \mathrm{U}$ of Amplitaq DNA polymerase (Perkin Elmer Cetus), $200 \mu \mathrm{M}$ deoxynucleotide triphosphates (Perkin Elmer Cetus), $1.25 \%$ formamide (33), $50 \mathrm{mM} \mathrm{KCl}, 10 \mathrm{mM}$ Tris$\mathrm{Cl}\left(\mathrm{pH} 8.3\right.$ at $\left.22^{\circ} \mathrm{C}\right), 1.5 \mathrm{mM} \mathrm{MgCl}, 0.01 \%$ gelatin, $100 \mathrm{pmol}$ of upstream and downstream primers, and water to a volume of 35 $\mu \mathrm{L}$. A $5-\mu \mathrm{L}$ aliquot of each $20-\mu \mathrm{L}$ reverse transcriptase reaction was added to the tubes, bringing the final volume of each tube to $50 \mu \mathrm{L}$. The samples were kept on ice until the block of the Perkins EImer Cetus thermocycler was at $94^{\circ} \mathrm{C}$, whereupon the samples were immediately placed into the block for $2 \mathrm{~min}$. Samples were amplified for 30 cycles of $1 \mathrm{~min}$ at $94^{\circ} \mathrm{C}$ followed by $1 \mathrm{~min}$ annealing at $49^{\circ} \mathrm{C}$ followed by $2 \mathrm{~min}$ of extension at $72^{\circ} \mathrm{C}$. Upon completing the final cycle, samples were incubated for 5 min at $72^{\circ} \mathrm{C}$.

Analysis and densitometry. Electrophoresis was performed on a $30-\mu \mathrm{L}$ aliquot of each sample through a $2.5 \%$ NuSieve $/ 1 \%$ Seakem (FMC, Rockland, ME) agarose gel in $1 \times$ Tris acetate running buffer for $3 \mathrm{~h}$ at $2 \mathrm{~V}$ direct current/cm constant current. Gel and running buffer each contained $0.5 \mu \mathrm{g}$ ethidium bromide/ $\mathrm{mL}$. The gels were illuminated with UV $280-\mathrm{nm}$ light and photographed with type 55 positive/negative polaroid film through a no. 15 wratten and $2 E \mathrm{EV}$ filter. The negative was transmissively scanned, and integrated intensities of the bands were determined with the Bio Image Visage 60 system (Millipore Corp., Milford, MA) which uses a high-speed two-dimensional array camera providing $512 \times 512$ pixel resolution.

Statistical analysis. The $t$ test was used for assessing differences in IL- 6 concentrations and IL- 6 mRNA content. The $t$ test with Bonferroni correction for multiple observations was used to assess differences in IL- 6 concentrations in supernatants of monocytes from different groups.

\section{RESULTS}

Production of IL- 6 by monocytes incubated for $24 \mathrm{~h}$ with various concentrations of IL- 6 is shown in Fig. 1 . In the absence of IL-6, supernatants of monocytes from adults contained more IL-6 $\left(6148 \pm 990 \mathrm{pg} / 10^{6}\right.$ monocytes, mean \pm SEM $)$ than did supernatants of monocytes from term $\left(2343 \pm 958 \mathrm{pg} / 10^{6}, p<\right.$ $0.05)$ and preterm monocytes $\left(441 \pm 198 \mathrm{pg} / 10^{6}, p<0.001\right.$ versus adult). Peak IL- 6 concentrations appeared in all groups when stimulated by IL- 1 at $\geq 5 \mathrm{ng} / \mathrm{mL}$. Combining plateau points, IL- 6 concentration from the adult monocytes was 28937 $\pm 1683 \mathrm{pg} / 10^{6}$ monocytes (mean $\pm \mathrm{SEM}$ ). This was significantly greater than plateau concentrations from term $(14117 \pm 2592$ $\left.\mathrm{pg} / 10^{6}, p<0.005\right)$ and preterm cells $\left(7186 \pm 1407 \mathrm{pg} / 10^{6}, p<\right.$ $0.005)$.

The production of IL- 6 by monocytes at various times after stimulation with IL- 1 is shown in Figure 2. IL-6 was undetectable in supernatants of all groups at $2 \mathrm{~h}$ after the addition of IL-1. At $6 \mathrm{~h}$ IL- 6 was present in the supernatants in all groups; however,

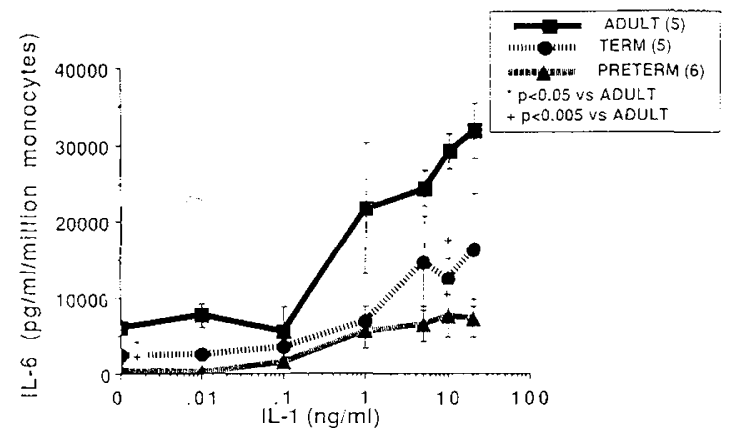

Fig. 1. Accumulation of IL-6 in supernatants of monocytes from adults and from term and preterm infants induced by various concentrations of $X L-1-\alpha$ keeping time constant.

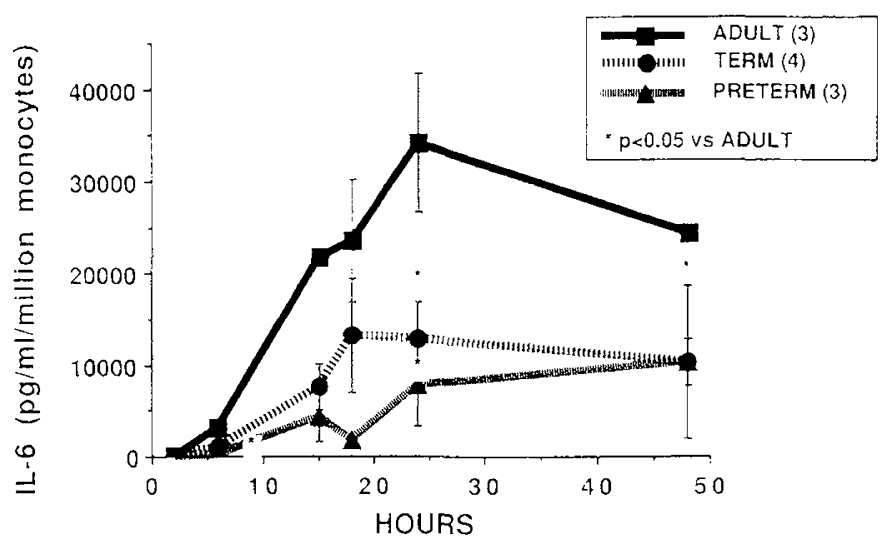

Fig. 2. Accumulation of IL-6 in supernatants from adults and from term and preterm neonates stimulated by IL-1 for varying lengths of time. 
levels were significantly lower in cells from preterm infants than in cells from adults $(p<0.05)$. Peak IL-6 production was noted in supernatants of cells from all groups by $24 \mathrm{~h}$, at which time concentrations were significantly greater in adult cells than in cells of neonates $(p<0.05)$. IL- 6 production was abolished by actinomycin $\mathrm{D}$.

As assessed by competitive PCR, monocytes from adults contained more IL-6 mRNA than did monocytes from neonates (Fig. 3), $(p<0.005)$. After $4 \mathrm{~h}$ of incubation, the RNA/DNA proportions were $100 \pm 0 \%$ for adult and $82 \pm 10 \%$ for neonatal monocytes. At $12 \mathrm{~h}$, IL-6 RNA/DNA proportions were $99 \pm 1 \%$ and $62 \pm 14 \%$ for adults and neonates, respectively $(p<0.05)$.

\section{DISCUSSION}

Newborn infants, particularly those delivered prematurely, have deficiencies in antibacterial defense (5-10). Among the best-characterized deficiencies are delayed maturation of B cells into antibody producing cells $(9-11,18)$, deficient $\mathrm{T}$-cell maturation $(12-14,18)$, and delayed cycling of hematopoietic progenitors after an infectious challenge (16). No unifying theory has been forwarded, however, to explain the concomitance of these deficiencies. IL-6 is a cytokine produced primarily by monocytes and macrophages in response to stimulation by IL-1 (22). The recognized actions of IL-6 (23-28) led us to postulate that its defective production by monocytes might underly developmental immune deficiencies in neonates.

Previous studies of IL-6 production by cells of neonates were performed using mixtures of various mononuclear cells or whole blood cell preparations. For instance, using "light-density" blood cells, composed predominantly of lymphocytes and monocytes, we previously observed less IL-6 accumulation in supernatants of cells of preterm neonates than in cells of adults (34). Using whole blood cell cultures, Yachie et al. (35) found no differences between term neonatal and adult cells in IL-6 accumulation after incubation with LPS derived from Escherichia coli. Interpretation of these studies is complicated by the fact that LPS from different bacterial species varies greatly in its capacity to induce
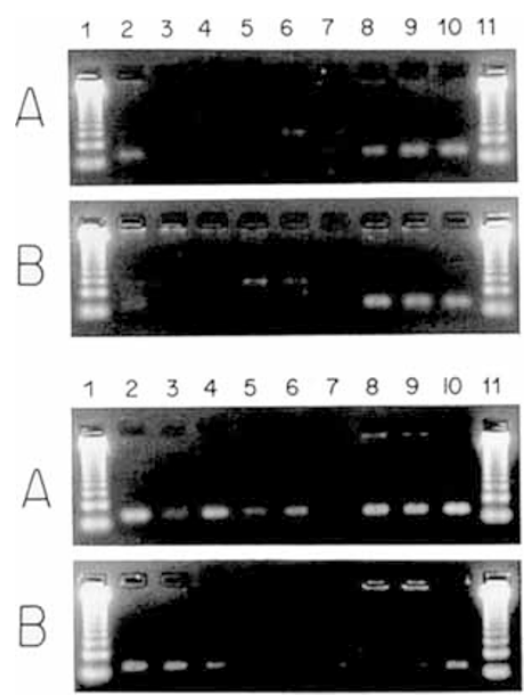

Fig. 3. IL- 6 mRNA content, as determined by competitive PCR, in monocytes from five term neonates (upper panel) at $4 \mathrm{~h}($ row $A)$ and 12 $\mathrm{h}($ row $B)$ and from five adults (lower panel) at $4 \mathrm{~h}($ row $A)$ and $12 \mathrm{~h}$ (row $B$ ) after incubation with IL-1. All IL-6 mRNA were run in triplicate. The lanes are as follow: 123-kb ladder (lanes $1 A, 1 B, 11 A$, and $11 B$ ), neonate 1 (lanes $2 A-4 A$ ), neonate 2 (lanes $5 A-7 A$ ), neonate 3 (lanes $8 A-10 A$ and $8 B-10 B$ ), neonate 4 (lanes $2 B-4 B$ ), and neonate 5 (lanes $5 B-7 B$ ). RNA samples from the adult subjects (lower panel) are as follow: $123-\mathrm{kb}$ ladder (lanes $I A, I B, I I A$, and $I I B$ ), adult 1 (lanes $2 A-$ $4 A$ and $2 B-4 B$ ), adult 2 (lanes $5 A-7 A$ ), adult 3 (lanes $8 A-10 A$ ), adult 4 (lanes $5 B-7 B$ ), and adult 5 (lanes $8 B-10 B$ ).
IL-6 (36) and also by the mixed cell populations used. Specifically, defective IL-6 production could be obscured under these conditions by the presence of various populations of cells, some of which produce and others that bind or degrade IL- 6 .

To reduce these variables, we devised a method for obtaining relatively pure populations of monocytes from blood using a technique of immunologically removing nonmonocytes from mononuclear cell preparations. The cells obtained using this method were $88-98 \%$ monocytes and, furthermore, the cells had not been subjected to selection procedures that result in activation, such as adherence to plastic or antibody attachment (37). Using this technique, we incubated monocytes from adults, term neonates, and preterm neonates with various concentrations of IL-1 for various periods of time and quantified IL- 6 in the supernates.

In the IL-1 dose-response experiments as well as the kinetic studies, we observed substantially less IL-6 in supernatants from term and, particularly, preterm cells than from cells of adults. The IL- 6 accumulation, was inhibited by transcriptional inhibitors, consistent with the study of Navarro et al. (37) showing that IL-6 $\mathrm{mRNA}$ production by monocytes is regulated by transcription after stimulation. The hypothesis that the reduced IL-6 accumulation in monocytes of neonates was the result of decreased transcription is also supported by our observation of less IL-6 mRNA in stimulated neonatal than adult monocytes.

Whether IL-6 production in response to inflammatory mediators is reduced in infants in vivo remains to be determined. If such a defect is observed, however, it might underlie several of the immune deficiencies of neonates.

\section{REFERENCES}

1. Siegel J, McCracken G 1981 Sepsis neonatorum. N Engl J Med 304:642-647 2. Freedman RM, Ingram DL. Gross I, Ehrenkranz RA, Warshaw JB, Baltimore RS 1981 A half century of neonatal sepsis at Yale. Am J Dis Child 135:140144

3. Weinstein R, McCracken G 1977 Pathogenesis and management of neonatal sepsis and meningitis. Curr Probl Pediatr 8:3-59

4. Zeligs BJ, Armstrong CD, Walser JB, Bellanti JA 1982 Age-dependent susceptibility of neonatal rats to group B streptococcal type III infection: correlation of scverity of infection and response of myeloid pools. Infect Immun 37:255263

5. Bennet R, Eriksson M, Zetterstrom R 1981 Increasing incidence of neonatal septiccmia: causative organisms and predisposing risk factors. Acta Paediatr Scand 70:207-210

6. Placzek MM, Whitelaw A 1983 Early and late onset neonatal septicemia. Arch Dis Child 58:728-731

7. Cates KL, Rowe JC, Ballow M 1983 The premature infant as a compromised host. Curr Probi Pediatr 13:1-63

8. Stiehm ER 1989 Immunologic Disorders of Infants and Children. WB Saunders, Philadelphia,

9. Dancis J, Osborn JJ, Kunz HW 1953 Studies of the immunology of the newborn infant: IV. Antibody formation in the premature infant. Pediatrics $12: 151-157$

10. Perovenzanno RW, Wetterlow LH, Sullivan CL 1965 Immunization and antibody response in the newborn infant: I. Pertussis inoculation within 24 hours of birth. N Engl J Med 273:959-965

11. Wu LYF, Blanco A, Cooper MD, Lawton AR 1976 Ontogeny of B lymphocyte differentiation induced by pokeweed mitogen. Clin Immunol Immunopathol 5:208-217

12. Andersson U, Bird AG, Britton S, Palacios R 1981 Humoral and cellular immunity in humans studied at the cell level from birth to two years of age. Immunol Rev 57:5-38

13. Hayward AR, Lawton AR 1977 Induction of plasma cell differentiation of human fetal lymphocytes: evidence for functional immaturity of $\mathrm{T}$ and $\mathrm{B}$ cells. J Immunol 1 19:1213-1217

14. Miyawaki T, Moriya N, Nagaoki T, Taniguchi N 1981 Maturation of B cell differentiation ability and $\mathrm{T}$ cell regulatory function in infancy and childhood. Immunol Rev 57:61-87

15. Bryson YJ, Winter HS, Gard SE, Fisher TJ, Stiehm ER 1980 Deficiency of immune interferon production by leukocytes of normal newborns. Cell Immunol 55:191-206

16. Christensen RD, Hill HR, Rothstein G 1983 Granulocyte stem cell (CFUc) proliferation in experimental group B streptococcal sepsis. Pediatr Res 17:278-280

17. Smith RT, Eitzman DV, Catlin ME, Wirtz EO, Miller BE 1964 Development of the immune response: characterization of the response of the human infant to Salmonella vaccines. Pediatrics 33:163-183

18. Tosato G, Magrath IT, Koski IR, Dooley NJ, Blaese RM 1980 B cell differ- 
entiation and immunoregulatory $\mathrm{T}$ cell function in human cord blood. $\mathrm{J}$ Clin Invest 66:383-388

19. Christensen RD, Rothstein G, Anstall HB 1982 Granulocyte transfusion in neonates with bacterial infection, neutropenia, and depletion of mature marrow neutrophils. Pediatrics 70:1-6

20. Erdman SH, Christensen RD, Bradley PP, Rothstein G 1982 Supply and release of storage neutrophils: a developmental study. Biol Neonate 41:132137

21. Bauer J, Ganter U, Geiger T, Jacobshagen U, Hirano T, Matsuda T, Kishimoto $\mathrm{T}$, Andus T, Acs G, Gerok W, Ciliberto G 1988 Regulation of interleukin-6 expression in cultured human monocytes and monocyte-derived macrophages. Blood 72:1134-1140

22. Tosato G, Jones KD 1990 Interleukin-1 induces interleukin-6 production in peripheral blood monocytes. Blood 75:1305-1310

23. Magurachi A, Hirano T, Tang B, Matsuda T, Horii Y, Nakajima K, Kishimoto T 1988 The essential role of B-cell stimulatory factor 2 (BSF-2/IL-6) for the terminal differentiation of B-cells. J Exp Med 167:332-344

24. Hirano T, Taga T, Nakano N, Yasukawa K, Kashiwamura S, Shimizu K, Nakajima K, Pyun KH, Kishimoto T 1985 Purification to homogeneity and characterization of human B-cell differentiation factor (BCDF or BSFp-2). Proc Natl Acad Sci USA 82:5490-5494

25. Uyttenhove C, Coulie PG, Van Snick J 1988 T-cell growth and differentiation induced by interleukin-HP-1/IL-6, the murine hybridoma/plasmacytoma growth factor. J Exp Med 167:1417-1427

26. Lotz M, Jirik F, Kabouridis P, Tsoukas C, Hirano T, Kishimoto T, Carson DA $1988 \mathrm{~B}$ cell stimulating factor 2 /interleukin-6 is a costimulant for human thymocytes and T lymphocytes. J Exp Med 167:1253-1258

27. Wong GG, Witel-Giannotti JS, Temple PA, Kriz R, Ferenz C, Hewick RM,
Clark SC, Ikebuchi K, Ogawa M 1988 Stimulation of murine hematopoietic colony formation by human IL-6. J Immunol 140:3040-3044

28. Gardner JD, Liechty KW, Christensen RD 1990 Effects of interleukin-6 on fetal progenitors. Blood 75:2150-2155

29. Sambrook J, Fritsch EF, Maniatis T 1989 Molecular Cloning: A Laboratory Manual. Cold Spring Harbor Laboratory Press, Cold Spring Harbor, New York

30. Wang A, Doyle M, Mark D 1989 Quantitation of mRNA by the polymerase chain reaction. Proc Natl Acad Sci USA 86:9717-9721

31. Gilliland G, Perrin S, Blanchard K, Bunn F 1990 Analysis of cytokine mRNA and DNA: detection and quantification by competitive polymerase chain reaction. Proc Natl Acad Sci USA 87:2725-2729

32. Bloch WA 1991 A biochemical perspective of the polymerase chain reaction. Biochemistry 30:2735-2747

33. Sarkar G, Kapelner S, Sommer S 1990 Formamide can dramatically improve the specificity of PCR. Nucleic Acids Res 18:7465

34. Liechty KW, Koenig JM, Mitchell MD, Romero R, Christensen RD 1991 Production of interleukin- 6 by fetal and maternal cells in vivo during intraamniotic infection and in vitro after stimulation with interleukin-1. Pediatr Res 29:1-4

35. Yachie A, Takano N, Yokoi T, Kato K, Kashahara Y, Miyawaki T, Taniguchi $\mathrm{N} 1990$ The capability of neonatal leukocytes to produce IL- 6 on stimulation assessed by whole blood culture. Pediatr Res 27:227-233

36. Loppnow H Libby P. Freudenberg M, Kraus JH, Weckesser J, Mayer H 1990 Cytokine induction by lipopolysaccharide (LPS) corresponds to lethal toxicity and is inhibited by nontoxic Rhodobacter capsulatus LPS. Infect Immun 58:3743-3750

37. Navarro S, Debili N, Bernoudin J, Vainchenker W, Doly J 1989 Regulation of the expression of IL-6 in human monocytcs. J Immunol 142:4339-4345

\section{Erratum}

In the article entitled "Requirements and Recommended Dietary Intakes of Protein during Infancy" by Samuel J. Fomon (Pediatr Res 30:391-395, 1991), an error was made in the last sentence discussing minimum protein content of infant formulas. It should read "For infants over 3 mo of age, a protein concentration of $1.8 \mathrm{~g} / 100$ kcal is considered adequate." The value given in the paper of $1.6 \mathrm{~g} / 100 \mathrm{kcal}$ was a typographical error. The author regrets this oversight. 